\title{
Cerebral aspergillosis in a patient with leprosy and diabetes: a case report
}

\author{
João Batista Alves Segundo ${ }^{1}$, Marcos Antonio Custódio Neto da Silva', Walbert Edson Muniz Filho², \\ Anna Cyntia Brandão Nascimento ${ }^{3}$, Flávia Castello Branco Vidal ${ }^{4}$, Geusa Felipa de Barros Bezerra², \\ Graça Maria de Castro Viana ${ }^{2}$ and Maria do Desterro Soares Brandão Nascimento $2,5,6^{*}$
}

\begin{abstract}
Background: Opportunistic fungi are dispersed as airborne, ground and decaying matter. The second most frequent extra-pulmonary disease by Aspergillus is in the central nervous system.

Case presentation: The case subject was 55 years old, male, mulatto, and an assistant surveyor residing in Teresina, Piauí. He presented with headache, seizures, confusion, fever and left hemiparesis upon hospitalization in 2006 at Hospital São Marcos. Five years previously, he was diagnosed with diabetes mellitus, and 17 months previously he had acne margined by hyperpigmented areas and was diagnosed with leprosy. Laboratory tests indicated leukocytosis and magnetic resonance imaging showed an infarction in the right cerebral hemisphere. Cerebrospinal fluid examination showed 120 cells $/ \mathrm{mm}^{3}$ and was alcohol-resistant bacilli negative. Trans-sphenoidal surgery with biopsy showed inflammation was caused by infection with Aspergillus fumigatus. We initiated use of parenteral amphotericin B, but his condition worsened. He underwent another surgery to implant a reservoir of Ommaya-Hickmann, a subcutaneous catheter. We started liposomal amphotericin B $5 \mathrm{mg} / \mathrm{kg}$ in the reservoir on alternate days. He was discharged with a prescription of tegretol and fluconazole.

Conclusion: This report has scientific interest because of the occurrence of angioinvasive cerebral aspergillosis in a diabetic patient, which is rarely reported. In conclusion, we suggest a definitive diagnosis of cerebral aspergillosis should not postpone quick effective treatment.
\end{abstract}

Keywords: Cerebral aspergillosis, Leprosy, Diabetes, Mycotic arteritis, Aspergillus fumigatus

\section{Background}

Opportunistic fungi are dispersed in nature as airborne particles from soil and mulch [1,2] and infection results from aspiration of conidia in the air, especially in humid environments [3]. Aspergillus fumigatus, Aspergillus flavus and Aspergillus niger species account for $95 \%$ of infections in humans [4]. Aspergillus infection becomes more important in immunocompromised patients, such as transplanted patients, human immunodeficiency virus carriers and patients undergoing cancer treatment [5]. The most common type of infection is invasive pulmonary aspergillosis

\footnotetext{
* Correspondence: cnsd_ma@uol.com.br

2Department of Pathology, Nucleum of Basic and Applied Immunology, Federal University of Maranhão, São Luís, Maranhão, Brazil

${ }^{5}$ Postgraduation Program in Maternal-Child Health, Nucleum of Basic and Applied Immunology, Portugueses Avenue, 1966, Bacanga. Prédio do CCBS, Bloco 3, Sala 3a, São Luís MA CEP 65080-805, Brazil

Full list of author information is available at the end of the article
}

(80-90\%) that can spread to the central nervous system (CNS) in $10-25 \%$ of cases. The second most common extra-pulmonary disease is that of the CNS [6].

The fungus can reach the brain through the blood by contiguity through the cribriform walls of the sphenoid sinus and cavernous sinus, optic nerve or vascular walls, or by direct implantation through neurosurgery [3]. The most common characteristic clinical symptoms of infection are headache, altered mental status and seizures [7]. Patients may manifest seizures or focal neurological signs from mass effect or stroke [8]. Diagnostics are performed by imaging and fungus can be measured in cerebrospinal fluid (CSF) using Sabouraud agar with culture medium $[4,9]$. Surgical treatment should be early and aggressive with the purpose of eliminating most of the necrotic material via sinus surgery or craniotomy [10].

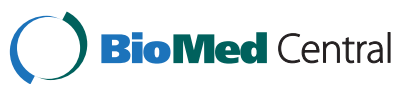

(c) 2014 Segundo et al.; licensee BioMed Central Ltd. This is an Open Access article distributed under the terms of the Creative Commons Attribution License (http://creativecommons.org/licenses/by/4.0), which permits unrestricted use, distribution, and reproduction in any medium, provided the original work is properly credited. The Creative Commons Public Domain Dedication waiver (http://creativecommons.org/publicdomain/zero/1.0/) applies to the data made available in this article, unless otherwise stated. 


\section{Case presentation}

This paper presents a case report of invasive aspergillosis of the CNS with mycotic carotid arteritis. Early diagnosis and appropriate treatment are essential for a good prognosis.

The case subject was a 55-year-old male, mulatto, who was an assistant surveyor residing in Teresina (PI). Five years previously, he was diagnosed with diabetes mellitus and started on treatment with neutral protamine hagedorn $(\mathrm{NPH})$ insulin + metformin. During this period, the patient had one episode of decreased level of consciousness.

Seventeen months previously, he presented with margined hyperpigmented dermatosis and was diagnosed with leprosy. He started treatment with dapsone for 14 months. He reported headaches six months ago, initially related to sinusitis treated by an otolaryngologist, but then started having seizures and was transferred to a neurologist who initiated anticonvulsants. The patient was not involved in gardening or agricultural activities and he was not a smoker. The patient worked as an assistant surveyor in the measurement of land, which could cause potential exposure to fungi from the air and soil.

Three months previously, he developed mental confusion, fever and left hemiparesis, and was admitted to São Marcos Hospital on 2 March 2006. He was prescribed $\mathrm{NPH}$ insulin, metformin $850 \mathrm{mg}$, rocefin $2 \mathrm{~g} /$ day, meticorten, tegretol $600 \mathrm{mg} /$ day and gardenal $100 \mathrm{mg} /$ day.

Laboratory and imaging tests were conducted. The hemogram on 2 March 2006 showed leukocytosis was 10.300 cells $/ \mathrm{mm}^{3}, \quad 0.7 \mathrm{mg} \%$ creatinine and glucose $160 \mathrm{mg} \%$. Chest X-ray showed pleural thickening with obliteration of the left costophrenic sinus on 4 March 2006. Computed tomography (CT) and magnetic resonance imaging (MRI) on 9 March 2006 showed right cerebral hemisphere infarction with hyperemia luxury, thrombosis of the carotid artery and sphenoid expansive process with cavernous sinus invasion, meningeal base and hydrocephalus (Figure 1). Lumbar puncture was performed with CSF examination (14 March 2006), which showed 120 cells $/ \mathrm{mm}^{3}$, $69 \%$ lymphocytes, $49 \mathrm{mg} \%$ protein and $87 \mathrm{mg} \%$ glucose with negative alcohol resistant bacilli (BAAR) in the CSF.

After examination, the patient was transferred from the clinical neurologist to a neurosurgeon, otolaryngologist and infectologist. He underwent trans-sphenoidal surgery with biopsy on 4 March 2006, which showed inflammation and intense infection by Aspergillus fumigatus by hematoxylin-eosin staining of biopsy samples (Figure 2).

Parenteral liposomal amphotericin B $(5 \mathrm{mg} / \mathrm{kg} /$ day $)$ treatment was initiated but there was worsening of symptoms with a decreased level of consciousness after intensification of convulsive seizures and vomiting. Liposomal amphotericin B is an alternative for the treatment of choice in some cases. Here, liposomal amphotericin B was initiated because of its lower cost compared to voriconazole.
A second surgery was performed on 17 May 2006 to implant a subcutaneous Ommaya - Hickmann reservoir and intra-ventricular catheter. Ventricular CSF was collected and examination showed 820 cells $/ \mathrm{mm}^{3}, 58 \%$ neutrophils, $106 \mathrm{mg} \%$ protein and $31 \mathrm{mg} \%$ glucose, with negative culture.

A new cranial CT scan showed right cerebral hemisphere infarction, and a catheter was placed into the right lateral ventricle and there was a reduction of hydrocephalus. Liposomal amphotericin B $5 \mathrm{mg} / \mathrm{kg}$ by reservoir on alternate days was initiated while maintaining NPH parenteral insulin and tegretol $1.600 \mathrm{mg} /$ day. The Infectious Diseases Society (IDSA) guidelines recommend $3-5 \mathrm{mg} / \mathrm{kg} /$ day of liposomal amphotericin B for treatment of cerebral aspergillosis. The scheme was administered on alternate days because of the patient's clinical condition and comorbidities.

The galactomannan test was not performed. Diagnosis of fungal infection was made by histopathology. Histopathological sections obtained by sphenoid biopsy demonstrated the presence of septate hyphae with dichotomous branching, suggesting Aspergillus spp.

There was progressive clinical improvement, seizures stopped, and the patient awoke, could feed orally and walk, with support, with reduced left hemiparesis. The patient was discharged on 14 June 2006 with a prescription of $600 \mathrm{mg} /$ day tegretol $+150 \mathrm{mg}$ fluconazol 2 capsules/day.

\section{Discussion}

Aspergillus dissemination to the CNS is a devastating complication of invasive aspergillosis [11-13]. CNS aspergillosis is the most lethal manifestation of Aspergillus infection with a mortality rate of $>90 \%$ [12].

Aspergillus infection often occurs in patients with weakened immune systems, such as transplant patients, HIV carriers and patients undergoing cancer treatment [14]. Other factors of immunosuppression include diabetes mellitus and leprosy, comorbidities previously shown by case reports [15]. Although people have contact with a variety of species of Aspergillus, only seven species are implicated in human infections. Aspergillus fumigatus is responsible for about $90 \%$ of infections, followed by Aspergillus flavus [16].

The main route of contamination of the CNS is hematogenous dissemination and contiguity from an adjacent area, such as the orbit or paranasal sinuses $[10,17,18]$. The hyphae may block intracerebral blood vessels, promote infarction that is commonly hemorrhagic and sterile, and can progress to a septic abscess $[9,14,19-22]$ that promotes mixed inflammation reactions, necrosis [21,22], vasculitis and mycotic aneurysms $[9,20,22]$.

There have been few reports of invasive cerebral aspergillosis in patients with diabetes [23], indicating the relevance of this study as the patient had diabetes 


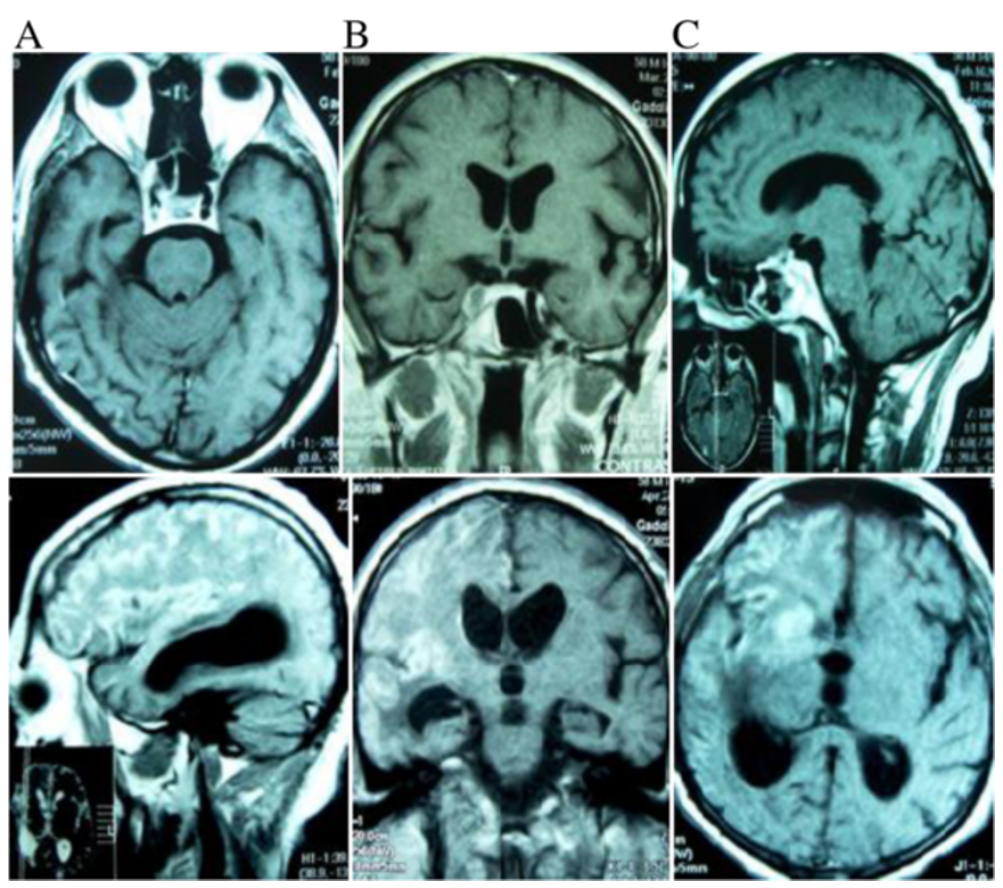

Figure 1 Magnetic Resonance Imaging in T1-weighted series of (A) axial, (B) coronal, and (C) sagittal sections. The hyperintense areas in topography of the right sphenoid sinus are evident in the three images, suggestive of fungal sinusitis. Hyperintense areas in the right superolateral cortical regions are evident in the three images, suggestive of cerebral infarction with luxury hyperemia by arteritis.

mellitus and leprosy as factors impairing the immune system. Oddo and Acuña [24], in a study of 5,612 necropsies, found 175 cases of opportunistic infection, and aspergillosis totaled 41 cases (23.4\%) ranking second, behind candidiasis.

Clinical manifestations result from the fungus pathogenicity and the host immune response [25]. The presence of seizures confirms the case reported by Nogales-Gaete et al. [3]. The diagnosis of aspergillosis is difficult and complex because of its nonspecific signs and symptoms [26], and is performed by imaging tests that show changes that must then be correlated with clinical, histopathological and laboratory tests (culture and serology).

Early diagnosis is very important for the management of mold infections of the CNS to allow for timely therapeutic intervention and prevention of neurologic sequelae. CT and MRI are important adjuncts in the detection of infection and in monitoring the course of therapy [27].

Detection of galactomannan antigen and 1,3- $\beta$-dglucan in CSF can assist in the diagnosis of cerebral aspergillosis and other mold infections [28,29]. However, as these antigens can also be produced by other species of fungi such
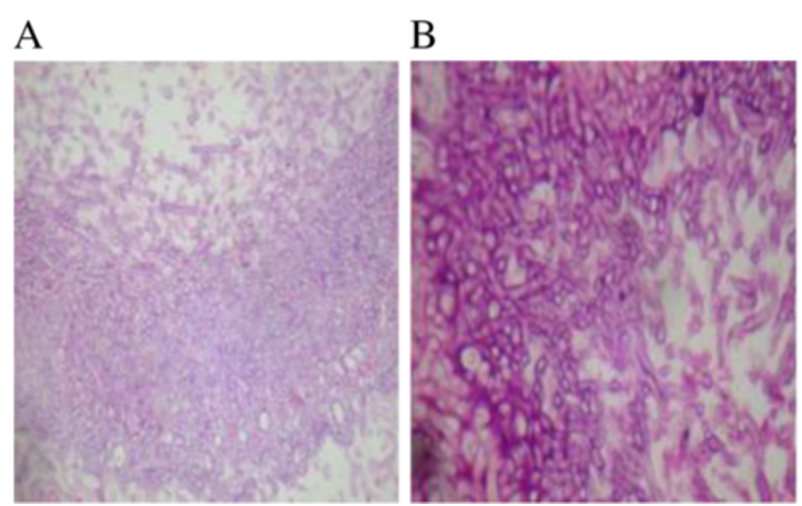

$\mathrm{C}$

Figure 2 Histopathological sections obtained by sphenoid biopsy demonstrating the presence of septate dichotomous hyphae by microscopy, suggesting Aspergillus spp. Hematoxylin Eosin (A) magnification is 40x and (B and C) 400x. 
as Fusarium, Scedosporium and Exserohilum rostratum, the detection of these antigens do not provide definitive diagnosis of cerebral aspergillosis [30]. A polymerasechain-reaction assay specific for aspergillus might be useful, but standardized platforms are lacking [31].

There have been few randomized trials on the treatment of invasive aspergillosis. Most observations of treatment of CNS aspergillosis are based on open-label studies. One randomized trial for invasive aspergillosis demonstrated a trend toward improvement of CNS aspergillosis in patients treated with voriconazole [32].

Itraconazole, posaconazole, or liposomal amphotericin B are recommended for patients who are intolerant or refractory to voriconazole. Among the amphotericins, liposomal amphotericin B showed favorable responses in some case reports [33-35], in agreement with the current study.

Nabika et al. [36] reported that surgical reduction of aspergilloma combined with local administration of antifungal was a good treatment option, corroborating the present study. According to Pianetti et al. [25], fungal infections observed as a mass should be treated by aggressive surgical resection. A patient with recurrence may benefit from the application of intralesional amphotericin $B$ [37]. There have been few descriptions of patients with cerebral aspergillosis that survived after undergoing surgery and antifungal therapy $[20,22]$.

\section{Conclusion}

This report has scientific interest because of the occurrence of angioinvasive cerebral aspergillosis in a diabetic patient, findings that are rare in the literature. In conclusion, a definitive diagnosis of cerebral aspergillosis should not postpone treatment.

\section{Consent}

This study was approved by the Ethics and Research of the University Hospital of the Federal University of Maranhão (233/09). The Statement of Informed Consent Form was presented to the patient and signed in accordance with Resolution No. 196/96. Written informed consent was obtained from the patient for publication of this Case Report and any accompanying images. A copy of the written consent is available for review by the Editor-inChief of this journal.

\section{Abbreviations \\ CNS: Central nervous system; CT: Computed tomography; MRI: Magnetic resonance imaging; CSF: Cerebrospinal fluid; NPH: Neutral protamine hagedorn; BAAR: Alcohol resistant bacilli; HIV: Human immunodeficiency virus; IDSA: Infectious diseases society.}

\section{Competing interests}

The authors declare that they have no competing interests.

\section{Authors' contributions}

JBAS and MDSBN participated in interpretation of data, and drafted and critically revised the manuscript. JBAS and MDSBN contributed to study design, interpretation of data, and critically revised the manuscript. MACNS and WEMF analyzed and assisted in interpretation of the data and assisted in drafting the manuscript. GFBB and GMCV contributed to interpretation of data and critically revised the manuscript. JBAS assisted in data acquisition and interpretation. All authors read and approved the final manuscript.

\section{Acknowledgments}

We thank the Hospital São Marcos, Teresina-PI for the availability of medical records.

\section{Author details}

'Medicine Course, Federal University of Maranhão, Gonçalves Dias Square, $\mathrm{s} / \mathrm{n}$, São Luís, Maranhão, Brazil. ²Department of Pathology, Nucleum of Basic and Applied Immunology, Federal University of Maranhão, São Luís,

Maranhão, Brazil. University Hospital of Federal University of Maranhão, Street Barão of Itapary, 227, Center, São Luís, Maranhão, Brazil. ${ }^{4}$ Department of Morphology, Federal University of Maranhão, São Luís, Maranhão, Brazil. ${ }^{5}$ Postgraduation Program in Maternal-Child Health, Nucleum of Basic and Applied Immunology, Portugueses Avenue, 1966, Bacanga. Prédio do CCBS, Bloco 3, Sala 3a, São Luís MA CEP 65080-805, Brazil. ' Medicine Course, State University of Maranhão, Caxias, Maranhão, Brazil.

Received: 18 June 2014 Accepted: 22 September 2014

Published: 4 October 2014

\section{References}

1. De Hoog GS, Josep G, Figueras MJ: Atlas dos Fungos Clínica, Volume 1. 2ath edition. Utrecht, Holanda: Voor Centraalbureau Schimmelcultures; 2000.

2. Richardson MD, Johnson EM: Fungal infection. In Opportunistic Fungal Infections. Malden, MA: [S.I.]: Blackwell. Science; 2000:30-36 [Pubmed].

3. Nogales-Gaete J, Navarrete C, González J, Sáez D, Quijada M, Espinoza L: Aspergilosis meningovascular: Caso clínico. Rev Chil Neuro-Psiquiatr 2005, 43(3):217-225

4. del Palácio A, Cuétara MS, Pontón J: El diagnóstico de laboratorio de La aspergilosis invasora. Rev Iberoam Micol 2003, 20(2):90-98.

5. Amromin GD, Gildenhorn VB: Massive cerebral Aspergillus abscess in a leukemic child. J Neurosurg 1971, 35(4):491-494.

6. Borges Sá M, Liebana-Fiederling A: Clinical presentations of nosocomial aspergillosis. Rev Iberoam Micol 2000, 17(3):S85-S89.

7. Azarpira N, Esfandiari M, Bagheri MH, Rakei S, Salari S: Cerebral aspergillosis presenting as a mass lesion. Braz J Infect Dis 2008, 12(4):349-351.

8. Segal BH: Aspergillosis. N Engl J Med 2009, 360:1870-1884

9. Grossman RI, Davis KR, Taveras JM, Beal MF, O'Carrol CP: Computed tomography in intracranial aspergillosis. J Comput Assist Tomogr 1981, 5(1):646-650.

10. Camarata PJ, Dunn DL, Farney AC, Parker RG, Seljeskog EL: Continual intracavitary administration of amphotericin B as an adjunct in the treatment of aspergillus brain abscess: case report and review of the literature. Neurosurgery 1992, 31:575-579.

11. Patterson TF, Kirkpatrick WR, White M, Hiemenz JW, Wingard JR, Dupont B, Rinaldi MG, Stevens DA, Graybill JR: Invasive aspergillosis: disease spectrum, treatment practices, and outcomes. I3 Aspergillus Study Group. Medicine (Baltimore) 2000, 79:250-260.

12. Walsh TJ, Hier DB, Caplan LR: Aspergillosis of the central nervoussystem: clinicopathological analysis of 17 patients. Ann Neurol 1985, 18:574-582.

13. Lin SJ, Schranz J, Teutsch SM: Aspergillosis case-fatality rate: systematic review of the literature. Clin Infect Dis 2001, 32:358-366.

14. Aschdown BC, Tien RD, Felsberg GJ: Aspergilosis of the brain and paranasal sinuses in imminocompromised patients: $C T$ and MRI imaging findings. Am J Roentgenol 1992, 162:155-159.

15. De Franco MF, Irina K: Ficomicose órbito-rino-cerebral associada à cetoacidose diabética: Registro de um caso. Rev Inst Med Trop Sao Paulo 1970, 12(5):354-363.

16. Miglets AW, Saunders WH, Leona A: Aspergillosis of the sphenoid sinus. Arch Otolaryngol 1978, 104:47-50

17. Denning DW: Invasive aspergillosis. Clin Infect Dis 1998, 26:781-805.

18. Wiles CM, Kocen RS, Symon L, Scaravilli F: Aspergillus granuloma of the trigeminal ganglion. J Neurol Neurosurg Psychiatry 1981, 44(5):451-455.

19. Enzmann DR, Brant-Zawadzki M, Britt RH: CT of central nervous system infections in immunocompromised patient. AJR Am J Roentgenol 1980, 135(2):263-267. 
20. Miaux Y, Ribaud P, Williams M, Guermazi A, Gluckman E, Brocheriou C, Laval-Jeantet M: MR of cerebral aspergillosis in patients who have had a bone marrow transplantation. AJNR Am J Neuroradiol 1995, 16(3):555-562

21. Beal MF, O'Carrol CP, Kleinman GM, Grossman Rl: Aspergillosis of the nervous system. Neurology 1982, 32:473-479.

22. Sharma RR, Gurusinghr NT, Lynch PG: Cerebral infarction due to aspergillus arterits following glioma surgery. Br J Neurosurg 1992, 6:485-490.

23. Norlinah MI, Ngow HA, Hamidon BB: Angioinvasive cerebral aspergillosis presenting as acute ischaemic stroke in a patient with diabetes mellitus. Singapore Med J 2007, 48(1):e1-e4.

24. Oddo D, Acuña G: Opportunistic infections in Chilean autopsy cases, 1960-1986. Bull Pan Am Health Organ 1982, 22:17-26.

25. Pianetti Filho G, Pedroso ERP, Gianetti AV, Darwich R: Aspergilose Cerebral Em Paciente Imunocompetente. Arq Neuro-Psiquiatr 2005, 63(4):1094-1098.

26. Lyons RW, Andriole VT: Fungal infection of CNS. Neurol Clin 1986, 4:159-170.

27. McCarthy M, Rosengart A, Schuetz AN, Kontoyiannis DP, Walsh TJ: Mold infections of the central nervous system. N Engl J Med 2014, 371:150-160.

28. Soeffker G, Wichmann D, Loderstaedt U, Sobottka I, Deuse T, Kluge S: Aspergillus galactomannan antigen for diagnosis and treatment monitoring in cerebral aspergillosis. Prog Transplant 2013, 23:71-74.

29. Mikulska M, Furfaro E, Del Bono V, Raiola AM, Di Grazia C, Bacigalupo A, Viscoli C: (1-3)- $\beta$-D-glucan in cerebrospinal fluid is useful for the diagnosis of central nervous system fungal infections. Clin Infect Dis 2013, 56:1511-1512

30. Tortorano AM, Esposto MC, Prigitano A, Grancini A, Ossis C, Cavanna C, Cascio GL: Cross-reactivity of Fusarium spp. in the Aspergillus galactomannan enzymelinked immunosorbent assay. $J$ Clin Microbiol 2012, 50:1051-1053

31. Reinwald M, Buchheidt D, Hummel M, Duerken M, Bertz H, Schwerdtfeger R, Reuter S, Kiehl MG, Barreto-Miranda M, Hofmann WK, Spiess B: Diagnostic performance of an Aspergillus-specific nested PCR assay in cerebrospinal fluid samples of immunocompromised patients for detection of central nervous system aspergillosis. PLoS One 2013, 8(2):e56706.

32. Herbrecht R, Denning DW, Patterson TF, Bennett JE, Greene RE, Oestmann JW, Kern WW, Marr KA, Ribaud P, Lortholary O, Sylvester R, Rubin RH M, Wingard JR, Stark P, Durand C, Caillot D, Thiel E, Pranatharthi HC, Hodges MR, Schlamm HT, Troke PF, Pauw B: Voriconazole versus amphotericin B for primary therapy of invasive aspergillosis. N Eng/ J Med 2002, 347:408-415.

33. Ng A, Gadong N, Kelsey A, Denning DW, Leggate J, Eden OB: Successful treatment of Aspergillus brain abscess in a child with acute lymphoblastic leukemia. Pediatr Hematol Oncol 2000, 17:497-504.

34. Khoury H, Adkins D, Miller G, Goodnough L, Brown R, DiPersio J: Resolution of invasive central nervous system aspergillosis in a transplant recipient. Bone Marrow Transplant 1997, 20:179-180

35. Coleman J, Hogg G, Rosenfeld J, Waters K: Invasive central nervous system aspergillosis: cure with liposomal amphotericin B, itraconazole, and radical surgery-case report and review of the literature. Neurosurgeny 1995, 36:858-863.

36. Nabika S, Kiya K, Satoh H, Mizoue T, Araki H, Oshita J: Local administration of amphotericin $B$ against aspergilloma in the prepontine cistern-case report. Neurol Med Chir 2007, 47(2):89-92.

37. Epstein NE, Hollingsworth R, Black K, Framer P: Fungal brain abscess (aspergillosis/mucormycosis) in two immunosuppressed patients. Surg Neurol 1991, 35:286-289

\section{Submit your next manuscript to BioMed Central and take full advantage of:}

- Convenient online submission

- Thorough peer review

- No space constraints or color figure charges

- Immediate publication on acceptance

- Inclusion in PubMed, CAS, Scopus and Google Scholar

- Research which is freely available for redistribution

Submit your manuscript at www.biomedcentral.com/submit
C Biomed Central 